臨床＼cjkstart超音波パルスドプラ法による等容性拡張期に

見られる左室内血流の検討

\author{
鹿児島大学医学部第二内科 \\ 黒岩 宣親〉 中村一彦 真田 純一 \\ 大重太真男橋本 修治
}

\title{
THE ANALYSIS OF THE BLOOD FLOW PATTERN OF THE LEFT VENTRICLE DURING ISOVOLUMIC RELAXATION PERIOD BY THE USE OF PULSED DOPPLER ECHOCARDIOGRAPHY
}

Nobuchika Kurorwa, MD, Kazuhiko Nakamura, MD, Jun-ichi Sanada, MD

Tamao OHShIge, MD and Shuji Hashimoto, MD

The Second Department of Internal Medicine, Faculty of Medicine, Kagoshima Univeritjy

\begin{abstract}
概要 超音波バルスドブラ法を用いて，等容性执張期に見られる左室内血流について，特徵的 パターン扰よび意義について健常例26名, 陳旧性心筋梗塞例43名で検討した。健常例では, 左 室中央部で心尖部へ向から層流性の血流信号が得られ，心音図上IIAより約 $20 \mathrm{msec}$ 前に始まり， ほぼIIAに一致してピークを有し急速流入血流の直前で消失する。同血流の持続時間は39才以 下の若年者群 $(n=14)$ で111 $\pm 22 \mathrm{msec}, 40$ 才以上の高年者群（n=12）で $137 \pm 27 \mathrm{msec}$ で, 高年 者群で有意に延長した。一方, 陳旧性心筋梗塞例では, 心尖部方向を向く群(以下 $\mathrm{A}$ 群： $\mathrm{n}=$ 20）心基部方向もしくは心尖部方向を向いたものが逆転して心基部方向を向く群（以下 $\mathrm{B}$ 群： $\mathrm{n}=12$ ) 明らかな血流の消失する群（以下C群： $\mathrm{n}=11$ ) の3群に分けられた，左室造影で等 容性払張期に左室を心基部側と心尖部側とに 2 分して検討すると，A群では心尖部側が心基部 側に比し，上り㧨張し血流は心尖部側へ向き，B群では逆に心基部側の抎張が強く心基部を向 き，C群では左室変形が少なく明らかな血流が出現しない事が示された，左室駆出率との関倸 では，健常例（ $N$ 群）との比較で， $N>A>B>C$ と有意差を生じた。等容性拡張期に見られる 血流は，梗塞部位やその広がりを含めた左室弛緩様式を反映すると共に，弛䋸速度評価に対す る有用性を持ち, 新しい左室驰緩能を表わす非観血的指標としての可能性が示唆された。
\end{abstract}

\section{緒言}

近年，超音波パルスドプラ法を用いて，非観血 的に心血管系の血流の検索が可能となり，種々の 分野でその有用性が報告されつつある。臨床的に は, 特に逆流性心疾患で診断招よび重症度評価京 で可能となつてきだー3). 左室内血流パターンに ついても検討が加兄られ，正常心では，収縮期に 駆出により左室流出路へ向から血流, 払張期に左 室流入路で，急速流入抢よび心房収縮による二峰 性の心尖部へ向から血流，さらに等容性収縮期に

〔昭和58年 5 月 7 日 第181回九州地方会推薦】
は左室流出路に招いて大動脈方向へ向から血流の 存在が報告されている4)57. 又, 等容性収縮期に見 られる血流に関しては，同血流の流速が左室駆出 率と正相関する事が報告され，閉鎖心腔に和ける 血流の重要性が示唆された5).一方, 等容性拡張期 には田中ら により，心尖部方向へ向から血流の 存在が報告されているが，その基本的特徵, 成因, 病態生理学的意義については末だ十分解明されて いない，今回著者らは，この等容性拡張期血流に ついて健常例および陳旧性心筋梗塞例を用いて検 討したので報告する。 


\section{対象および方法}

対象は健常例26例, 陳旧性心筋梗塞例43例の計 69例である．健常例はポランティア16例および胸 痛を訴えたが冠動脈造影，左室造影にて異常を認 めなかつた 10 例で, 年令 $24 \sim 64$ 才 $(39.2 \pm 14.3$ 才, mean $\pm S D)$ 男性 21 名，女性 5 名である。陳旧性心 筋梗塞例は, 年令33～70才 (56.7 8 8.4才) 男性 36 名, 女性 7 名であり, 全例とも冠動脈造影, 左室 造影を施行した。

超音波パルスドプラ法の使用装置扣よび記録方 法については, 既報らのように行なつた。時相分析 は 5 心拍の平均値を用いた. 左室造影は, Sones力

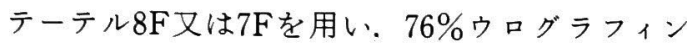

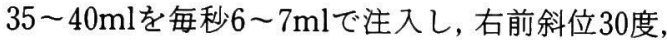
左前斜位 60 度を秒 60 コマで撮影した。分析に際し ては，右前斜位のものを用いて，拡張末期，収縮 末期，僧帽弁開放直前のフレームを重㸚合わせて トレースし，体積はKennedyらの方法7により求 めた。 心基部側（以下Base）と心尖部側（以下 Apex)の分類については，大動脈弁輪部中点と心 尖部を結ぶ線を二等分して心基部側と心尖部側と した。等容性拡張期時相は，収縮未期フレームよ り僧帽弁開放直前のフレームまでとした，等容性 抎張期時相の心尖部側の面積の拡大率と, 心基部 側の面積の拡大率の比は図 1 のシェーマに示すよ

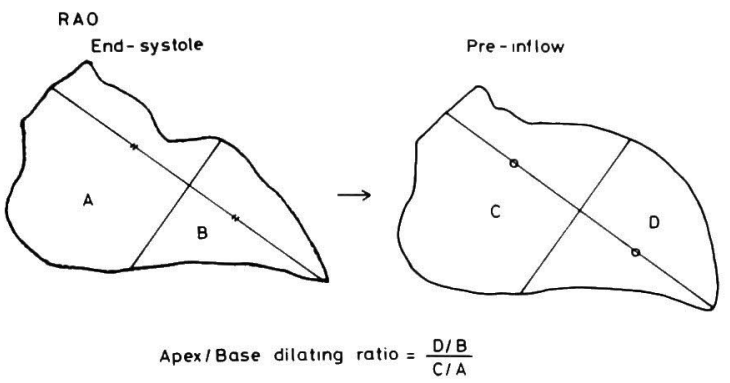

図 1 。心尖部側/心基部側の拡大率の比

うにApex $/$ Base = D/B/C/Aで計算した.

結果

図 2 に健常例の左室中央部における血流ドプラ 信号を示す収縮期駆出血流を示す左室流出路側 一向から血流と，急速流入血流により心尖部方向 へ向から血流との間に, 矢印に示すように心尖部 側へ向から立ち上りの急峻な層流性の血流を認め る。本血流はドプラ装置のtime delayを考虑に入 れると時相的には心音図上IIAよりわずか前に始 まり，急速流入血流の直前に消失しており，核 等容性拡張期に一致するので以下便宜的に isovolumic relaxation flow（以下IRFと略す）と 名付けた。

IRFは健常者の全例に認められた。本血流は, 概 ね左室中央部で流速が最大となり，良好な血流信

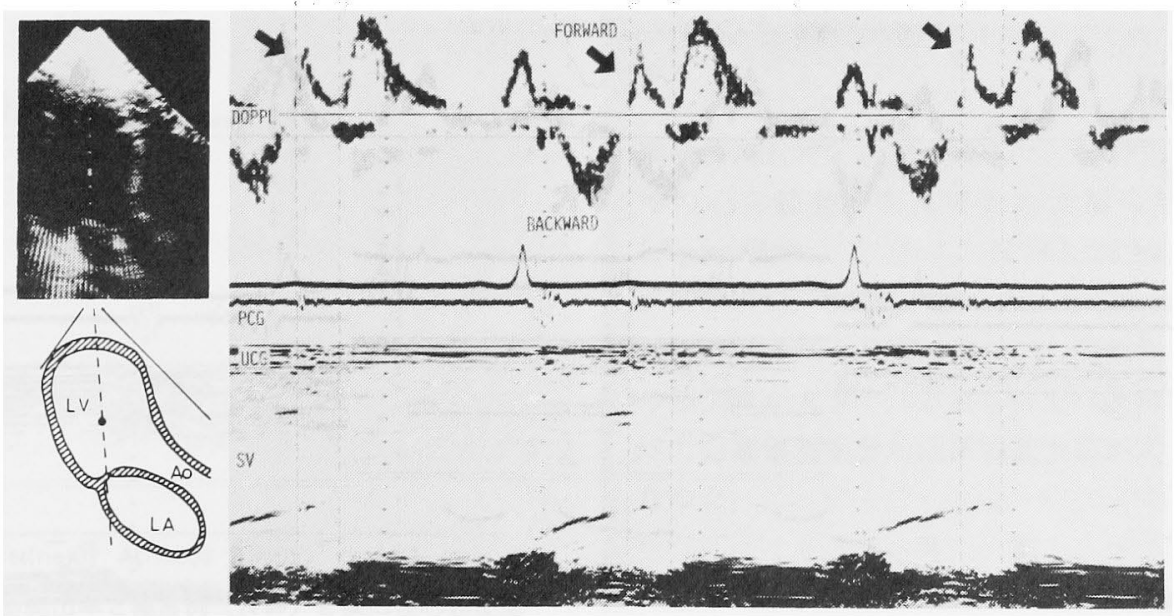

図 2, 健常例左室中央部における血流ドプラ信号 
表 1 ，健常者例における若年者群と高年者群の比較

\begin{tabular}{l|cc} 
& 若年者群 $(\mathrm{n}=14)$ & 高年者群 $(\mathrm{n}=12)$ \\
\hline 年 令 & $24 \sim 38(25.5 \pm 1.4)$ & $45 \sim 64(55.1 \pm 5.9)$ \\
$\mathrm{R}-\mathrm{R}$ 間隔 (msec) & $908 \pm 170$ & $955 \pm 109$ \\
$\mathrm{II} A-\mathrm{IRF}$ 開始 (msec) & $-18 \pm 7$ & $-21 \pm 12$ \\
$\mathrm{II} A-\mathrm{IRF}$ ピーク (msec) & $-3 \pm 3$ & $14 \pm 25$ \\
IRF 持続時間 (msec) & $111 \pm 22$ & $137 \pm 27$ \\
IRF ピーク流速 $(\mathrm{Hz})$ & $810 \pm 221$ & $888 \pm 239$ \\
& & (平均士SD)
\end{tabular}

号が得られる傾向にあつたため，以下の検討は同 部位にて行なつた。

健常例26例を, 39才以下の若年者群 $(n=14)$ と 40 才以上の高年者群 $(n=12)$ に分け, そのIRFの 分析結果を表 1 に示す. IRFピーク流速は, 若年者 群 $810 \pm 221 \mathrm{~Hz}$ ，高年者群 $888 \pm 239 \mathrm{~Hz}$ で有意差な く, IRF持続時間は, 若年者群 $111 \pm 22 \mathrm{msec}$, 高年 者群 $137 \pm 27 \mathrm{msec} て ゙$ 高年者群で有意に延長してい た。心音図上IIAからIRF開始までは, 若年者群一 $18 \pm 7 \mathrm{msec}$, 高年者群 $-21 \pm 12 \mathrm{msec}$, IIA り IRF 流速のピークまでは, 若年者群 $-3 \pm 3 \mathrm{msec}$, 高年

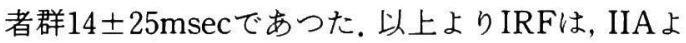
り約 $20 \mathrm{msec}$ 前に始まり IIA 付近でピークを有する
事が示された。

次に陳旧性心筋梗塞群のドプラ血流信号を検討 した. 図 3 に示す如く, 健常例と同様に心尖部方 向を向く血流を呈する群（以下 $\mathrm{A}$ 群： $\mathrm{n}=20$ ), 健常例とは逆向きの心基部を向く血流もしくは, まず心尖部を向きその後逆転して心基部を向く血 流を呈する群 (以下 B 群： $\mathrm{n}=12$ ), 明らかな血 流が消失する群 (以下 C 群 $\mathrm{n}=11$ ) の 3 群に分 けられた. 以下これらの 3 群と, 左室造影を施行 した健常群 (以下 $\mathrm{N}$ 群： $\mathrm{n}=10$ ) についての比較 検討を行なつた。

表 2 に冠動脈に $75 \%$ 以上の有意の狭窄を示す部 位拄よび, 左室壁異常運動を呈する部位を心尖部

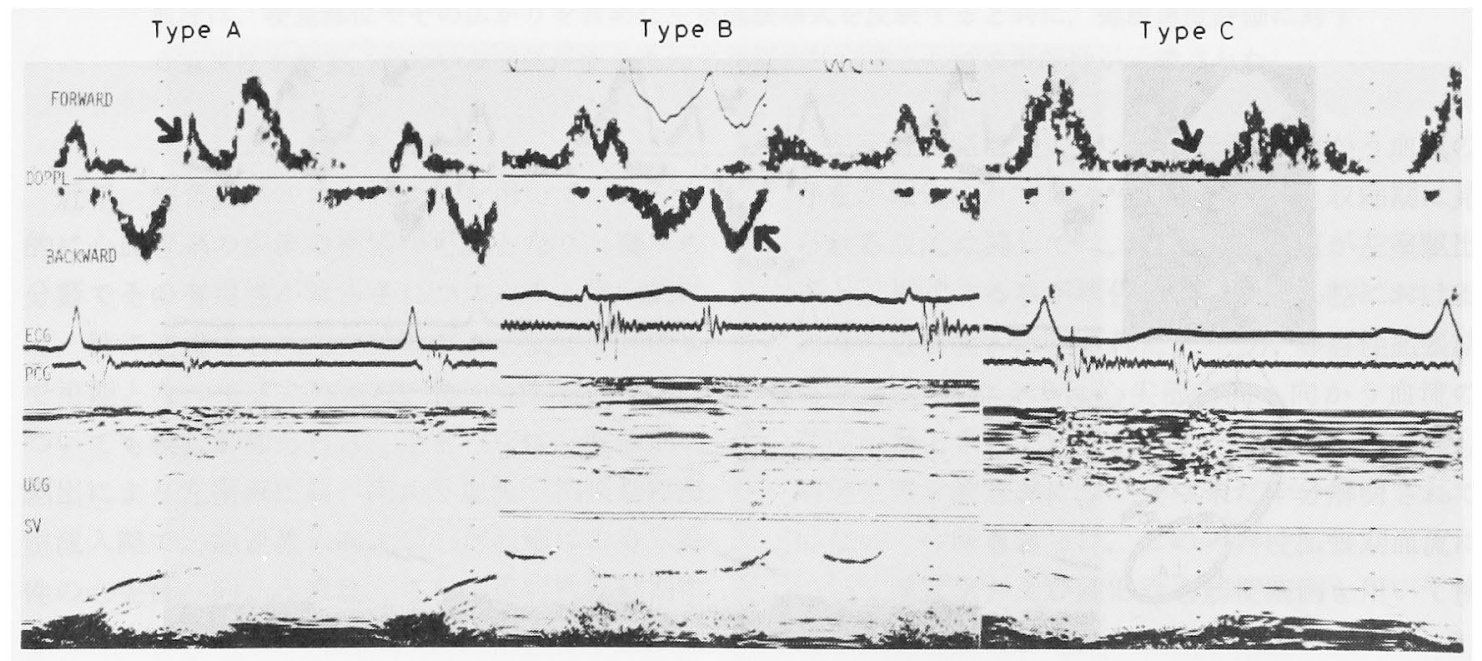

図 3. 陳旧性心筋梗塞例における血流ドブラ信号 
表 2、IRF各群と冠動脈病变および左室壁異常運動を有する部位

\begin{tabular}{|c|c|c|c|c|c|c|c|}
\hline \multirow{2}{*}{ IRF } & \multirow{2}{*}{ Type } & \multicolumn{3}{|c|}{ 冠䯄眽病变 } & \multicolumn{3}{|c|}{ 左室壁病変 } \\
\hline & & LAD & LCX & $\mathrm{RCA}$ & Apical & Basal & Both \\
\hline A & $(n=20)$ & 10 & 11 & 12 & 7 & 3 & 10 \\
\hline B & $(n=12)$ & 8 & 3 & 3 & 10 & 0 & 2 \\
\hline C & $(n=11)$ & 7 & 2 & 2 & 3 & 0 & 8 \\
\hline
\end{tabular}

側をApical，心基部側をBasal，両側にわたる場合 をBothで示した，B群では，全例心尖部側の壁異 常運動を有していた。図 4 に各群の左室駆出率を 示す. N群 $77 \pm 8 \%, A$ 群 $66 \pm 12 \%, B$ 群 $52 \pm 11 \%$,

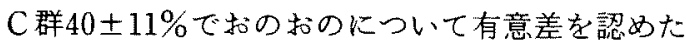
$(\mathrm{N}>\mathrm{A}>\mathrm{B}>\mathrm{C}$ )。図 5 K左室収縮末期容量 (Endsystolic volume： ESV) より僧帽弁開放直前の 容量 (Pre-infow volume：PIV)への增加率PIV/

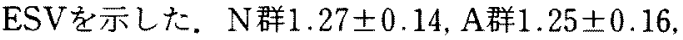

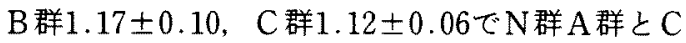
群との間では有意にC 群の増加率は低く, 容量の 增加率が少ない結果となつた。図 6 に左室造影右

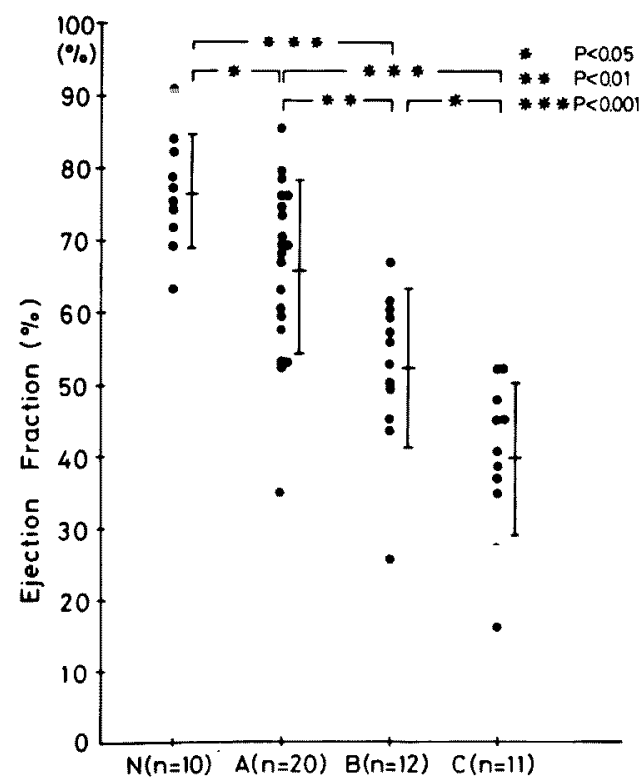

図 4，左室駆出率之健常例（N群）と陳旧性心筋梗塞 3 群との比較

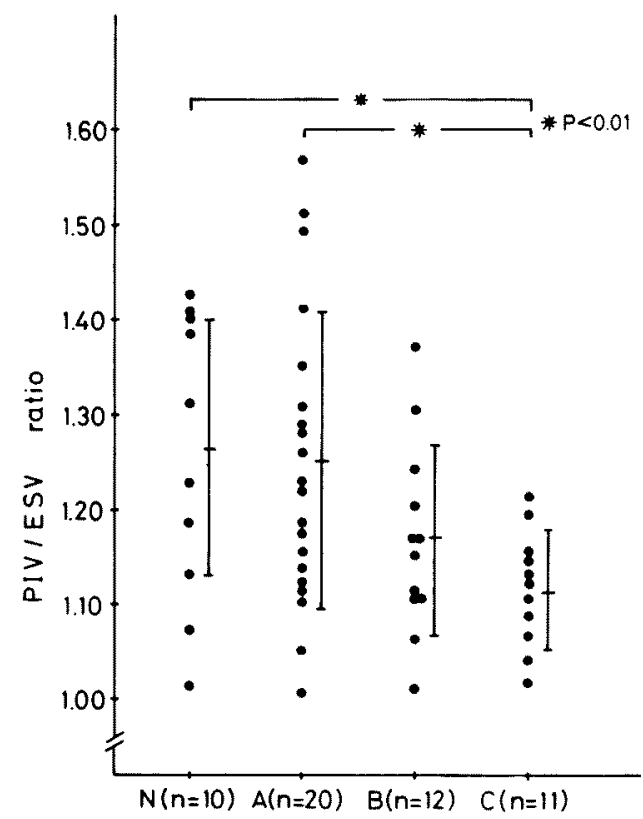

図 5。僧帽弁開放直前左室容量 (PIV)/収樎末期容量 (ESV) と各群との比較

前斜位における収縮末期より，僧帽并開放直前ま での心尖部側と心基部側の面積の拡大率の比 (Apex/Base) を示寸 $\mathrm{N}$ 群1.22 $00.22, \mathrm{~A}$ 群

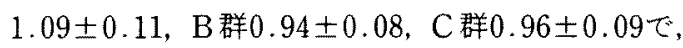
$\mathrm{N}$ 群 $\mathrm{A}$ 群では心基部に比べて心尖部側半分の面積 の桩大率が大きく、 $\mathrm{B}$ 群 $\mathrm{C}$ 群では逆に心尖部に比 べて心基部側半分の面積の㹡大率が大きい結果と なつた。

\section{考案}

近年超音波パルスドプラ法を用いて非観血的に 左室内血流の検索が可能となり，正常心を含め虚 


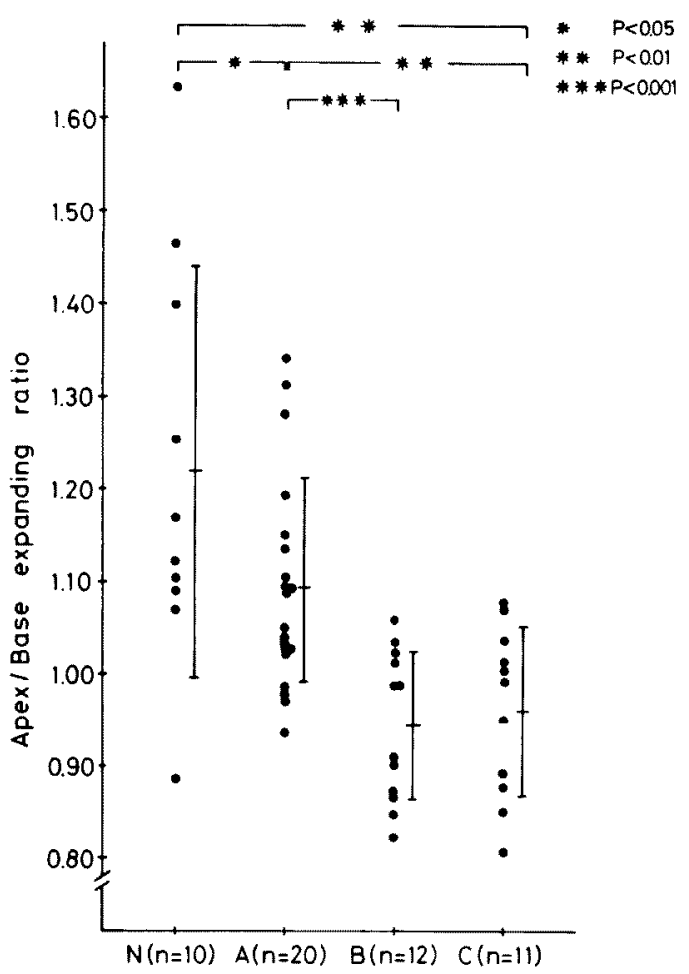

图 6. 心头部側/心基部側の払大率と各群との比較

血心でも詳細な報告がなされている48)。しかしな がら等容性抾張期の血流については, その存在は 報告されているが,十分な解明がなされていない 一方, 正常心扰上び病的心で, 等容性拡張期時相 に左室の変形をきたす事が以前より報告さ $れ^{10111)}$, 又, 本時相での弛緩特性の变化が病的心の 早期の示標として注目されるようになり，等容性 抎張期時相での左室内血流の動態は興味あるとこ ろである。

今回の健常例の検討では, IRFは心音図上IIAよ り約 $20 \mathrm{msec}$ 前に始まり，ほぼIIAに一致してピー クを有し，急速流入血流の直前に終る事が示され た。流速は，左室中央部付近で最大となり平均 850 $\mathrm{Hz}$ 程度であつた。超音波ビーム方向と流入路の血 流に対する角度をほぼ平行と仮定すると，流速は 約 $23 \mathrm{~cm} /$ 秒であり, 急速流入血流流速の半分程度 であつた，左室号緩の始まりは駆出期後半に存在 すると考古られているが，正確な時相は不明であ
る ${ }^{12)}$ ，後述するようにIRFの成因として左室弛緩 による変形が考えられるので, IRFがIIAより約 20 msec前に始まる事は, 左室弛緩の開始は少なく之 むIIAより約 $20 \mathrm{msec}$ 前に存在すると考えられる。 又, IIAに一致してピークを有する事は, IRFが大 動脈升閉鎖機序にも合目的に働く事が示唆され る. 左室等容性拓張期時間 (以下IRT)は, 大動脈 弁閉鎖より僧帽弁開放までの時相で, 左室弛緩速 度をある程度反映するが，大動脈切痕圧，左房纴 扣よび心拍数により影響される事は従来言われて おり，年令と共に延長するとの報告当見られ る13114)，IRFはIIAより前に始まるため，従来の IRTより高値となるが左室弛緩速度を表わす指標 として，IRTと同様の意義をもつものと考えられ る.今回の検討では, 若年者群 $111 \pm 22 \mathrm{msec}$, 高年 者群 $137 \pm 27 \mathrm{msec} て ゙$ 高年者群で有意に延長した が，これは従来のIRTでの成績 ${ }^{14}$ に矛盾しないと 考学られる。

等容性払張期時相において，左室容量はわずか に増加する事が報告されている(10)111，著者らの健 常例の検討では，その増加率PIV/ESVは1.27で Ruttleyら ${ }^{109}$ の 1.24 と良く一致する.著者らはさら にその容量の変化を検討する意味で，心基部側半 分と心尖部側半分の面積の拡大率の比Apex/ Baseを求めた。健常例㧍よび陳旧性心筋梗塞の A 群ではおの拉の1.22，1.09で心尖部側の拡大率が 大きく，心尖部側に容量の増加が多く血流は心尖 部側へ生ずる可能性が示唆される。これに対し，

B 群では0.94で心基部側の拡大率が大きく，血流 は心基部側へ向くものと考光られる，健常例に拉 、て等容性抎張期に左室内血流が心尖部を向く成 因として，(i) 大動脈并閉鎖に伴う左室内への逆 流，(ii）左室他緩に伴ら左室变形により生ずる血 流等が考えられるが，上記左室造影所見怙よび大 動脈升直下で必ずしも流速が最大とならない事を 考古合政ると，(ii）の要因が大きいと考えられ る。

陳旧性心筋梗塞例では，IRFは心尖部方向へ向 く血流を示す $\mathrm{A}$ 群，心基部方向へ向く血流もしく は，まず心尖部方向を向きその後逆転して心基部 
方向を向く血流を示す B 群，明らかな血流の消失 するC群の三つのパターンに分けられた，A群で は，B群，C群之比べ左室駆出率が良好なものが

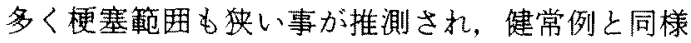
のパターンを呈するるのと，心基部側に壁異常運 動を有し，等容性扗張期に心尖部側の拡張が大き く血流が心尖部方向を向く生禹者が存在す るものと考兵られる、B群では, 左室駆出率がや や低下し全例心尖部に壁異常運動を有しているた め，心尖部に比へ心基部側の㹡張が大きく，血流 は心基部方向を向くものと思われる，C群では， 左室駆出率が低下し梗塞範囲が広くコンプライア ンスも低下し，等容性拡張期に打ける容量の変化 率が小さくなり左室変形が少なく，明らかな血流 が出現し得ないものと考えられた。

今回の検討では，IRF波形が有意に左室駆出率 々関係するとの結果が得られたが，その出現時相 が等容性払張期という閉鎖心腔である事を考慮す ると, 梗塞部位やその広がりを含めた左室他緩様 式を反映するとともに，弛緩速度評洒に対する有 用性を持つと思われ，新しい左室驰緩能を表わす 非観血的指標としての可能性が示唆された。

\section{結論}

超音波パルス ドプラ法に上り，等容性执張期 に左室内血流を認めた。本血流は，左室矽緩によ り生ずると考えられ，局所壁運動を反映し，新し い左室弛緩能を表わす非観血的指標としての可能 性が示唆された。

\section{文献}

1）中村一彦，他：超音波パルストプラ法による三尖 手閉鎖不全症の診断。日超医論文集 $39: 257$, 1981

2) Miyatake $K$, et al: Evaluation of tricuspid regurgitation by pulsed Doppler and two- dimentional echocardiography. Circulation 66 : $777,1982$.

3）真田 純一，他：超音波バルストプラ法による僧 帽手閉鎖不全症の評価。超音波医学 $10 ： 5,1983$.

4) Matsuo $\mathrm{H}$, et al: Intracardiac flow dynamics with bi-directional ultrasonic pulsed Doppler technique. Jap Circ J $41: 515,1977$.

5）真田純一，他：超音波バルスドプラ法による左室 内等容性收綰期血流の検討。呼吸と循環 $31: 81$, 1983.

6) 田中元淔, 他：心内血流の䠛床的評価のために不 可久な要件上生体信号の多重記録の有用性，日超 医䧻文集 $37: 25 ， 1980$.

7) Kennedy JW, et al: Left ventricular volume and mass from single plane cineangiogram. A comparison of anteroposterior and right anterior oblique methods. Amer Heart J 80:343, 1970.

8) 中村一彦，他：超音波パルスドプラ法に上る虚血 珄心疾患の左室内血流の検討。超音波学 10 ： 32, 1983.

9）黑岩宣彩，他：超音波パルスドプラ法による抬張 早期一急速流入血流の前に認められる左室内血流 について，日超医論文集 $41: 359 ， 1982$.

10) Ruttley MS, et al : Shape and volume changes during "isovolumic relaxation" in normal and asynergic ventricles. Circulation 50:306, 1974.

11) Gibson DG, et al: Analysis of left ventricular wall movement during isovolumic relaxation and its relation to coronary artery disease. Brit Heart J 38: 1010, 1976.

12）飯场昌彦：心室の弛䋸特性，心臟力学。阿郎 裕 監修，朝倉亩店，東京，1982，p142。

13) Harrison TR, et al: The relation of age to the duration of contraction, edjection and relaxation of the normal human heart. Amer Heart J $67: 189,1964$.

14）宮武邦夫，他：虚血性心疾患の心嘰能：超音波一 ルスドプラ法による心時相分析。臨床心音图 3 ： 411, 1973. 